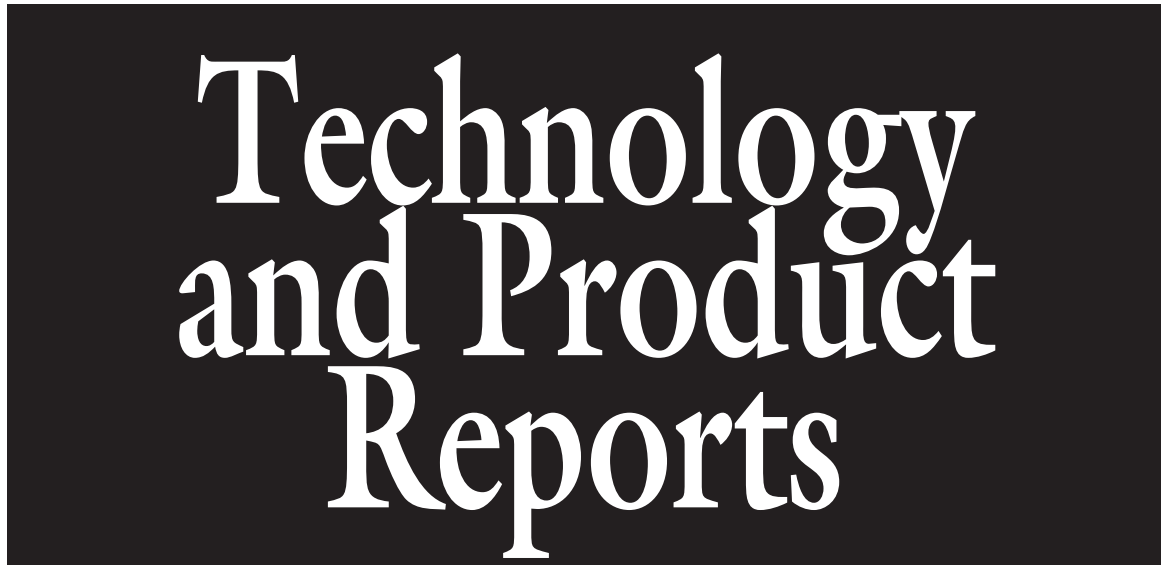

\section{The Effects of Colored Plastic Mulches and Row Covers on the Growth and Yield of Okra}

\author{
Garry G. Gordon ${ }^{1,3}$, Wheeler G. Foshee III $^{2}$, Stewart T. Reed ${ }^{1}$, \\ James E. Brown ${ }^{2}$, and Edgar L. Vinson $\mathrm{III}^{2}$
}

AdDitionAl INDEX wORDs. Abelmoschus esculentus, soil temperature, air, stem diameter

Summary. Okra (Abelmoschus esculentus 'Clemson Spineless') was grown on an Orangeburg sandy loam soil in Shorter, AL. Okra was direct-seeded in single rows. Treatments consisted of five mulch colors: black, white, red, silver, and blue installed either with or without spun-bonded row cover. Soil temperatures were 4 to $7{ }^{\circ} \mathrm{C}$ lower than air temperatures in all treatments. The use of darker (black, blue, red) -colored plastic mulches increased early and total yield of okra compared with bare soil with and without row cover. Increased soil and air temperatures did not always correlate to an increase in yield. It can be concluded that the use of dark plastic mulch is advantageous to growers of okra in climates that do not have cool springs, but the added use of row covers to plastic mulch has no effect on growth and yield. The profit of marketable okra produced using a row cover was \$1.37 versus $\$ 1.35$ per pound without a cover in 2003 and $\$ 1.28$ versus $\$ 1.29$ per pound in 2004. Blue plastic mulch is $\approx \$ 0.08$ per foot more expensive than black plastic. Our data do not show an economic advantage for blue over black mulch for okra, but the positive effect cited by other authors may be more pronounced with leafy vegetables.

$\mathrm{P}$ lastic (polyethylene) mulches have been used in vegetable production in the United States since the 1950s. Black polyethylene plastic mulch is the standard plastic mulch used in vegetable production. Black plastic alters the plant's growing environment by generating warmer soil temperatures (Dodds et al., 2003; Hanna et al., 2003) and holding more soil moisture (Ham et al., 1991; Lamont, 1993) than bare soil. Researchers using black plastic instead of

${ }^{1}$ USDA-ARS, Subtropical Horticultural Research Station, 13601 Old Cutler Road, Miami, FL 33158

${ }^{2}$ Department of Horticulture, 101 Funchess Hall, Auburn University, AL 36849

${ }^{3}$ Corresponding author. E-mail: Gary.Gordon@ARS. USDA.GOV. bare soil have recorded higher yields (Brown et al., 1995; Leib et al., 2002; Summers and Stapleton, 2002), earlier harvests (Bonanno and Lamont, 1987; Ibarra et al., 2001; Lamont,
1993), and cleaner fruit (Brown and Channell-Butcher, 2001; Loughrin and Kasperbauer, 2002), all attributed to soil temperature and moisture differences under plastic mulch. Sometimes black plastic mulches can create soil temperatures that are too high and this will cause deleterious effects on plant growth (Díaz-Péréz et al., 2000; Orzolek and Murphy, 1993). Other mulch colors besides black have been used by growers and researchers in vegetable production. White plastic mulch has been shown to generate cooler soil temperatures than black plastic (Díaz-Péréz and Batal, 2002; Lamont, 1993). White plastic is preferred during the summer growing season in warmer regions of the world compared with black plastic because it has the ability to maintain soil moisture while having cooler temperatures than black plastic. The use of silver plastic mulch has resulted in less insect-transmitted disease (Csizinszky et al., 1995; Lamont et al., 1990) in certain vegetable crops. Red plastic mulch has shown increased yield in tomato (Solanum lycopersicum) (Decoteau et al., 1989) and other crops (Decoteau et al., 1990; Kasperbauer, 1992).

Row covers are used to insulate a plant's growing environment to promote early yield. Floating spunbonded polyester row covers are used with various vegetable crops (Shadbolt et al., 1962; Wells and Loy, 1985). Floating row covers have been shown to alter the plant's microenvironment by increasing temperatures for the crop during the day and into the night (Arancibia and Motsenbocker, 2002). The use of row covers with plastic mulch has shown to sometimes have a greater effect (Powell, 2000) and sometimes less effect (Lamont et al., 2000) on plant yield than the use of plastic

\begin{tabular}{llll}
\hline $\begin{array}{l}\text { Units } \\
\begin{array}{l}\text { To convert U.S. to SI, } \\
\text { multiply by }\end{array}\end{array}$ & U.S. unit & SI unit & $\begin{array}{l}\text { To convert SI to U.S., } \\
\text { multiply by }\end{array}$ \\
\hline 0.3048 & $\mathrm{ft}$ & $\mathrm{m}$ & 3.2808 \\
9.3540 & gal/acre & $\mathrm{L} \cdot \mathrm{ha}^{-1}$ & 0.1069 \\
2.54 & inch $(\mathrm{es})$ & $\mathrm{cm}$ & 0.3937 \\
0.4536 & $\mathrm{lb}$ & $\mathrm{kg}$ & 2.2046 \\
1.1209 & $\mathrm{lb} / \mathrm{acre}$ & $\mathrm{kg} \cdot \mathrm{ha}^{-1}$ & 0.8922 \\
0.0254 & mil & $\mathrm{mm}$ & 39.3701 \\
70.0532 & $\mathrm{oz} / \mathrm{acre}$ & $\mathrm{g} \cdot \mathrm{ha}^{-1}$ & 0.0143 \\
1.1692 & $\mathrm{pt} / \mathrm{acre}$ & $\mathrm{L} \cdot \mathrm{ha}^{-1}$ & 0.8553 \\
2.3385 & $\mathrm{qt} / \mathrm{acre}$ & $\mathrm{L} \cdot \mathrm{ha}^{-1}$ & 0.4276 \\
$\left({ }^{\circ} \mathrm{F}-32\right) \div 1.8$ & ${ }^{\circ} \mathrm{F}$ & ${ }^{\circ} \mathrm{C}$ & $\left(1.8 \times{ }^{\circ} \mathrm{C}\right)+32$
\end{tabular}


mulch alone. The response of a plant to row covers is greatly dependent on the temperature in the region during the time the row covers are installed (Bonanno and Lamont, 1987; Contreras Magana and Sánchez del Castillo, 1990).

The use of row covers with plastic mulch has been shown to generate earlier and increased yields than row covers and plastic mulch used separately (Brown and Channell-Butcher, 1999a; Farías-Larios et al., 1998; Purser, 1993). Brown et al. (1998) observed that row covers with plastic mulch increased yield in sweetpotato (Ipomoea batatas). Gerber and Brown (1982) found superior and earlier yields of muskmelon (Cucumis melo) with the combination of row covers and plastic mulch. Cucumber (Cucumis satious) exhibited a positive increase in early and total yield with the addition of row covers to plastic mulch (Wolfe et al., 1989).

Phytochrome is the photoreceptor responsible for light-regulated growth responses. The phytochrome molecule is a dissolvable chromoprotein with subunits that are made up of a linear tetrapryrrole chromophore covalently linked to a polypeptide of 120 to 127,000 molecular weight depending on the plant species (Pratt, 1982; Vierstra et al., 1984). Phytochrome receptors within plant cells have the ability to detect wavelengths from 300 to $800 \mathrm{~nm}$. Red (R) light is absorbed from 660 to $680 \mathrm{~nm}$ and far-red (FR) light is absorbed from 730 to $740 \mathrm{~nm}$ (Decoteau et al., 1993; Kasperbauer, 1999; Rajapakse and Kelly, 1994). Tomato plants grown with red plastic mulch produced higher marketable yields than those grown with black plastic mulch (Decoteau et al., 1989). The researchers who conducted this study believed that their findings were related to the effects that light reflected from red plastic mulch had on the plant's phytochrome regulatory system. Orzolek et al. (2000) found silver and red plastic mulches reflected higher FR:R ratios than other mulch colors used in their study. This study also revealed an increase in marketable fruit yield in tomato using silver or red mulch as compared with standard black plastic. Bell pepper (Capsicum annuum) plants grew taller and were heavier when grown on red plastic, which exposed them to a greater FR:R ratio compared with other plastic mulches used in the experiment (Decoteau et al., 1990).

Plants have shown a multitude of different responses when treated with blue (wavelength 400 to $500 \mathrm{~nm}$ ) light. Blue light treatments have shown to affect morphological, metabolic, and directional reactions in plants (Senger and Schmidt, 1994). Some of the documented findings on plant response to blue light include: phototropism (Lipson, 1980; Shropshire, 1980) enzyme synthesis (Hart, 1988; Ruyters, 1982), chloroplast development in leaves (Akoyunoglou et al., 1980), and stomatal opening (Hart, 1988). Hatt et al. (1993) and Kasperbauer and Loughrin (2004) have found white plastic mulch to reflect more blue light than the other colored mulches used in their experiments. Antonious et al. (1996) reported that turnip (Brassica rapa) roots grown on white plastic mulch, which reflected the largest amounts of blue light, had the least distinct or mildest flavor. Decoteau et al. (1988) reported that shorter stems and more auxiliary growth could result from the blue light reflected from the use of white plastic mulch with tomato. Fieldgrown cotton (Gossypium spp.) produced more boll fibers and seeds per plant when grown on ground covered with colored plastic mulches that reflected less blue light resulting in higher FR:R ratios (Kasperbauer and Thibodeaux, 1997).

Research on growing vegetable crops with various colored plastic mulches along with spun-bonded row covers is limited. The purpose of this study was to evaluate the effects of colored plastic mulches with and without row covers on growth and earliness of fruit production on okra.

\section{Materials and methods}

The research was conducted at the E.V. Smith Research Experiment Station in Shorter, AL. The soil type is an Orangeburg sandy loam (fineloamy siliceous thermic Typic Kandiudult). Field plots to evaluate the effects of colored plastic mulches and row covers on the growth and production of 'Clemson Spineless' okra were established in May 2003 and Apr. 2004. The plots were $10 \mathrm{ft}$ long and $5 \mathrm{ft}$ wide. The colored plastic mulches and plastic drip irrigation lines were applied simultaneously on raised beds ( 6 inches in height) prepared with a plastic layering machine attached to a medium-sized tractor. The experimental plots were arranged in a randomized complete block design with four replications of each treatment. Each of the four replications represented a different block. Okra was direct-seeded into the field on 8 May 2003 and 28 Apr. 2004. A soil $\mathrm{pH}$ of 7.0 was recorded in Year 2003 and 6.2 in 2004. Treatments consisted of five mulch colors: black (BPM), white (WPM), red (RPM), silver (SPM) (all from Ken-Bar, Reading, MA), and blue [BLUPM (Pliant, Schamburg, IL)], installed either with or without spun-bonded row cover [RC (Ken-Bar)]. Drip irrigation tape applied together with the BPM was left in place for all treatments. The silver, red, white, and black plastic mulch were all 1.5 mil thick and 36 inches wide. The blue plastic mulch was 1.25 mil thick and 48 inches wide. The row cover was $1.7 \times 0.77 \mathrm{~m}$. The drip irrigation tape was $1 \mathrm{~cm}$ in diameter with 12-inch emitter

Table 1. Fertilizer and insecticide applied preplant and fertilizer, insecticide, and herbicide applied in season to okra plots with colored plastic mulch with and without row cover or bare soil in 2003 and 2004 at Shorter, AL.

\begin{tabular}{|c|c|c|}
\hline \multirow[b]{3}{*}{ Amendment } & \multicolumn{2}{|c|}{ Year } \\
\hline & 2003 & 2004 \\
\hline & \multicolumn{2}{|c|}{ Preplant (oz/acre) } \\
\hline Phosphorus & 0.14 & 0.29 \\
\hline Potassium & 0.57 & 0.57 \\
\hline Magnesium & 0.57 & 0.14 \\
\hline Calcium & 3.14 & 2.14 \\
\hline Nitrogen & 955 & 1012 \\
\hline \multirow[t]{2}{*}{ Chloropicrin } & 4790 & 4790 \\
\hline & \multicolumn{2}{|c|}{ Preplant $(\text { lb/acre })^{z}$} \\
\hline \multirow[t]{2}{*}{ Methyl bromide } & 300 & 300 \\
\hline & \multicolumn{2}{|c|}{ In season (lb/acre) } \\
\hline $20 \mathrm{~N}-8.73 \mathrm{P}-16.6 \mathrm{~K}$ & 47.7 & 104.8 \\
\hline Calcium nitrate & 54.9 & - \\
\hline \multirow[t]{2}{*}{ Carbaryl } & 4.0 & 1.2 \\
\hline & \multicolumn{2}{|c|}{$(\mathrm{gal} / \mathrm{acre})^{z}$} \\
\hline Trifluralin & 0.13 & 0.13 \\
\hline Spinosad & 0.007 & - \\
\hline Malathion & 0.13 & 0.13 \\
\hline Sethoxydim & 0.13 & 0.13 \\
\hline Glyphosate & 0.25 & 0.50 \\
\hline
\end{tabular}


Table 2. Analysis of variance results for the effects of mulch color by row cover, year, block, and their interactions on okra plant height, fresh weight, stem diameter, and marketable and unmarketable yields (early and total yields) at Shorter, AL.

\begin{tabular}{|c|c|c|c|c|c|c|c|c|c|c|c|}
\hline Treatment & $\begin{array}{c}\text { Plant } \\
\text { ht }\end{array}$ & $\begin{array}{c}\text { Fresh } \\
\text { wt }\end{array}$ & $\begin{array}{l}\text { Stem } \\
\text { diam }\end{array}$ & $\begin{array}{c}\text { Early } \\
\text { marketable } \\
\text { yield }\end{array}$ & $\begin{array}{l}\text { Early } \\
\text { cull } \\
\text { yield }\end{array}$ & $\begin{array}{c}\text { Total } \\
\text { marketable } \\
\text { yield }\end{array}$ & $\begin{array}{c}\text { Total } \\
\text { cull } \\
\text { yield }\end{array}$ & $\begin{array}{l}\text { Total } \\
\text { yield }\end{array}$ & $\begin{array}{c}\text { No. } \\
\text { branches }\end{array}$ & $\begin{array}{l}\text { Soil } \\
\text { temp }\end{array}$ & $\begin{array}{c}\text { Air } \\
\text { temp }\end{array}$ \\
\hline Mulch color ${ }^{\mathrm{z}}$ & $* * *$ & $* * *$ & $* * *$ & $\star * *$ & $* * *$ & $* * *$ & $* * *$ & $* * *$ & $* * *$ & $* * *$ & $* * *$ \\
\hline Year $^{\mathrm{x}}$ & $* * *$ & NS & $* * *$ & $* * *$ & $* * *$ & $* * *$ & $* * *$ & $* * *$ & * & $* * *$ & $* * *$ \\
\hline Block $^{w}$ & NS & NS & NS & NS & NS & NS & NS & NS & NS & NS & NS \\
\hline
\end{tabular}

${ }^{\mathrm{z}}$ Bare soil, black plastic, blue plastic, red plastic, silver plastic, and white plastic mulch.

Plots with and without row cover.

2003 and 2004.

"Each replication was a block.

NS = nonsignificant at the $0.05 \mathrm{Plevel} ;{ }^{*},{ }^{* *},{ }^{* *}=$ significant at the $0.05,0.01$, and $0.001 P$ levels, respectively.

spacing. Bare soil (BS) plots with and without RC were used as controls. Six 364 - $\mathrm{ft}$ strips of black plastic were installed over beds. Several sections in the black plastic $(10 \times 5 \mathrm{ft})$ were cut out, removed from the soil, and replaced with an equal size of white, blue, red, or silver plastic mulch. Uncut sections remaining in place served as the BPM treatment and cut sections left uncovered served as controls. The same day plastic mulches were installed in the field, 8 May 2003 and 28 Apr. 2004, okra was directseeded with three seeds for each of the 10 holes placed in the plastic mulch or bare soil treatments. The okra was thinned to one plant per hole after $14 \mathrm{~d}$ of growth and then 2-m-wide row cover strips were spread over designated treatments on 22 May 2003 and 12 Apr. 2004. Row cover strips were tucked into the soil around the edges of each plot and left to float loosely in an effort not to hinder plant growth as well as to prevent the loss of captured heat. The row covers were removed when okra plants developed flowers.

Soil temperature to a depth of 4 inches was measured with a soil probe thermometer (Taylor ${ }^{\circledR}$ Switchable Digital Thermometer; Taylor Precision Products, Oak Brook, IL). Air temperature was measured with Taylor ${ }^{\circledR}$ Indoor/Outdoor Thermometers (Taylor Precision Products) with sensors attached to heat-conducting wires and placed in the center of each plot at 5 inches above ground level. Temperatures were recorded for $14 \mathrm{~d}$ from 30 May to 15 June 2003 for air and soil temperatures. In 2004, air temperature was recorded for $12 \mathrm{~d}$ from 20 May to 7 June and for soil temperature $15 \mathrm{~d}$ from 14
May to 7 June from 1200 to $1300 \mathrm{HR}$ on each day. The air temperatures were recorded during the okra vegetative stage.

The stem diameter was taken with a digital caliper (Model 500196; Mitutoyo Digimatic, Kanagawa, Japan). Caliper measurements were taken 2 inches above ground level around the base of plants. Canopy heights were taken with a meter stick by measuring from the base of the plant to the tip of the highest leaf. Plant heights were taken from all treatments in both years on the day that the row covers were removed. The amount of branching per okra plant was determined by hand counting all branches over 3 inches in length. The okra yield was separated based on appearance (size, shape, color, and presence of insect or disease damage) into marketable and cull fruit and the weight of each group recorded. Yields for each treatment were determined by weighing marketable and cull fruit at each harvest date.

Preplant fertilizer and pesticides applied to okra plots in the years 2003 and 2004 were in accordance with soil testing recommendations from $\mathrm{Au}^{-}$ burn University Soil Testing Laboratory (Auburn, AL) and are given in Table 1. No limestone was added to okra plots either year. Before laying the plastic mulch, methyl bromide (67\% methyl bromide $+33 \%$ chloropicrin; Soil Chemicals, Hollister, CA) was applied to the soil as a fumigant at a rate of $300 \mathrm{lb} /$ acre on 17 Apr. 2003 and 27 Mar. 2004, respectively. Liquid calcium nitrate $\left[\mathrm{Ca}\left(\mathrm{NO}_{3}\right)_{2}\right]$ fertilizer was injected into the soil through plastic drip fertigation tubes from 30 May to 28 Aug. 2003 and nitrogen $(\mathrm{N})$, phosphorus $(\mathrm{P})$, and potassium $(\mathrm{K})$ as $20 \mathrm{~N}-8.73 \mathrm{P}-16.6 \mathrm{~K}$ from 30 May to 28 Aug. 2003. Nitrogen, $\mathrm{P}$, and $\mathrm{K}$ as $20 \mathrm{~N}-8.73 \mathrm{P}-16.6 \mathrm{~K}$

Table 3. Effect of row cover and plastic mulch color on early and total okra yield for marketable, cull, and the combined total of marketable plus cull fruit in 2003 at Shorter, AL.

\begin{tabular}{|c|c|c|c|c|c|}
\hline \multirow[b]{2}{*}{ Treatment } & \multicolumn{2}{|c|}{ Early yield $(\mathrm{lb} / \text { acre })^{\mathrm{z}}$} & \multicolumn{3}{|c|}{ Total yield (lb/acre) } \\
\hline & Marketable & Cull & Marketable & Cull & Combined total \\
\hline \multicolumn{6}{|l|}{ Row cover } \\
\hline None & $353 \mathrm{a}^{\mathrm{y}}$ & 161 & $9,865 \mathrm{~b}$ & 5,435 & $15,300 \mathrm{~b}$ \\
\hline Yes & $186 \mathrm{~b}$ & 127 & $12,630 \mathrm{a}$ & 6,396 & $19,026 \mathrm{a}$ \\
\hline \multicolumn{6}{|l|}{ Mulch color } \\
\hline Bare soil & 225 & 38 & $7,762 \mathrm{c}$ & $3,740 \mathrm{c}$ & $11,502 \mathrm{c}$ \\
\hline Black & 311 & 134 & $13,738 \mathrm{a}$ & $7,662 \mathrm{a}$ & $21,401 \mathrm{a}$ \\
\hline Blue & 295 & 229 & $12,084 \mathrm{ab}$ & $6,875 \mathrm{ab}$ & $18,959 \mathrm{ab}$ \\
\hline Red & 272 & 187 & $11,275 \mathrm{ab}$ & $5,593 \mathrm{~b}$ & $16,868 \mathrm{~b}$ \\
\hline Silver & 307 & 181 & 11,197 b & $5,977 \mathrm{ab}$ & $17,174 \mathrm{~b}$ \\
\hline White & 208 & 97 & $11,429 \mathrm{ab}$ & $5,644 \mathrm{~b}$ & $17,074 \mathrm{~b}$ \\
\hline
\end{tabular}

\footnotetext{
${ }^{\mathrm{z}}$ First 2 weeks of harvest; $1 \mathrm{lb} / \mathrm{acre}=1.1209 \mathrm{~kg} \cdot \mathrm{ha}^{-1}$
}

${ }^{y}$ Mean separation within columns was determined by Fisher's least significant difference test. Within a column and factor, treatment means followed by the same letter are not significantly different at $P<0.05$. Means followed by no letter were not significantly different at $P<0.05$. 
were applied to plots in 2004. Trifluralin at $1 \mathrm{pt} /$ acre a.i. (Treflan; Bayer CropScience, Research Triangle Park, NC) was applied in May 2003 and 2004. In May 2003, 1 qt/ acre a.i. of glyphosate (Round-Up; Monsanto, St. Louis, MO) was applied between the rows of the okra plots. In May 2004, 2 qt/acre a.i. of glyphosate was applied. Carbaryl (Sevin 80S; Bayer CropScience) was applied at a rate of $4 \mathrm{lb} /$ acre a.i. in June 2003 and at $2 \mathrm{pt} /$ acre a.i. in June 2004. Sethoxydim (Poast; Bayer CropScience) was applied at 1.2 L.ha ${ }^{-1}$ a.i. on 25 July 2003 and 23 June 2004. Malathion (Pestanal®; Superleco, Superleco Park, PA) and spinosad (SpinTor; Dow AgroSciences, Indianapolis, IN) were applied on 18 July and 8 Aug. 2003, respectively. Okra was harvested from 3 July to 8 Sept. 2003 and from 21 June to 27 Aug. 2004. Fruit were picked on Monday, Wednesday, and Friday during the harvest period. Early yields were defined as okra fruit collected during the first 2 weeks of harvest, which were from 3 to 16 July 2003 and 21 June to 4 July 2004. All data were analyzed using SAS (Version 9.1; SAS Institute, Cary, NC). The effects of mulch color, row cover, replication (block), year, and their interactions on selected plant physical characteristics and yield components were tested by the analysis of variance (ANOVA) procedure. Where main effects were insignificant, those variables were dropped from the model and the ANOVA rerun. Because there were no significant block effects, the data were run in a factorial model with interaction. Temperature data were analyzed using the general linear model, repeated measures procedure of SAS (SAS Institute). Both air and soil temperatures were reported as the mean for values measured over the recording period during each year. Unless otherwise indicated, mean separation for all variables was accomplished with the Fisher's least significant difference test at $P<0.05$.

\section{Results and discussion}

Significant differences between treatments were found for mulch color (Table 2). The row cover effect was significant for all treatments except total cull and year had a significant effect on all but fresh weight. There were significant mulch-by- cover-by-year treatment interactions for early yield components; however, by the end of harvest, these effects had vanished. All yield data are presented by year for early versus total yield comparisons. Table 3 lists yield data for 2003. Early yields, both marketable and cull, tended to be higher in plots without row covers, but this trend reversed in time. The combined total yields (marketable yield plus cull) were greater with row covers than without. Significantly lower yields were produced with bare soil than with any colored mulches used. Blue plastic mulch resulted in the highest early yield and maintained its productivity through harvest yielding the second highest combined total yield. At harvest, black plastic mulch resulted in the highest combined total yield.

There were no significant differences in early marketable and cull okra yields among the mulch color treatments in 2003. The bare soil produced the lowest marketable and combined total yields and black plastic produced the highest. On average, marketable yields were $66 \%$ of the total fruit produced with row cover

Table 4. Effect of row cover and plastic mulch color on early and total okra yield for marketable, cull, and the combined total of marketable plus cull fruit in 2004 at Shorter, AL.

\begin{tabular}{|c|c|c|c|c|c|}
\hline \multirow[b]{2}{*}{ Source } & \multicolumn{2}{|c|}{ Early yield $(\mathrm{lb} / \mathrm{acre})^{\mathrm{z}}$} & \multicolumn{3}{|c|}{ Total yield (lb/acre) } \\
\hline & Marketable & Cull & Marketable & Cull & Combined tota \\
\hline \multicolumn{6}{|l|}{ Row cover } \\
\hline None & $964 a^{y}$ & $500 \mathrm{a}$ & $7,579 \mathrm{~b}$ & 3,009 & $10,587 \mathrm{a}$ \\
\hline Yes & $689 \mathrm{~b}$ & $199 \mathrm{~b}$ & 8,897 a & 3,212 & $12,108 \mathrm{a}$ \\
\hline \multicolumn{6}{|l|}{ Mulch color } \\
\hline Bare soil & $329 \mathrm{~d}$ & $114 \mathrm{~d}$ & $3,027 \mathrm{~d}$ & $1,128 \mathrm{c}$ & $4,155 \mathrm{c}$ \\
\hline Black & $1,020 \mathrm{ab}$ & $502 \mathrm{ab}$ & $10,803 \mathrm{a}$ & $4,423 \mathrm{a}$ & $15,226 \mathrm{a}$ \\
\hline Blue & $1,081 \mathrm{a}$ & 648 a & $10,019 \mathrm{ab}$ & $4,115 \mathrm{ab}$ & $14,133 \mathrm{a}$ \\
\hline Red & $1,101 \mathrm{a}$ & $377 \mathrm{bc}$ & $7,668 \mathrm{c}$ & $2,958 \mathrm{~b}$ & $10,626 \mathrm{~b}$ \\
\hline Silver & 754 bc & $258 \mathrm{~cd}$ & $7,932 \mathrm{bc}$ & $2,937 \mathrm{~b}$ & $10,868 \mathrm{~b}$ \\
\hline White & $678 \mathrm{c}$ & $199 \mathrm{~cd}$ & $9,978 \mathrm{ab}$ & $3,103 \mathrm{~b}$ & $13,081 \mathrm{ab}$ \\
\hline
\end{tabular}

${ }^{\mathrm{z}}$ First 2 weeks of harvest; $1 \mathrm{lb} /$ acre $=1.1209 \mathrm{~kg} \cdot \mathrm{ha}^{-1}$.

y Mean separation within columns was determined by Fisher's least significant difference test. Within a column and factor, treatment means followed by the same letter are not significantly different at $P<0.05$. Means followed by no letter were not significantly different at $P<0.05$

Table 5. Effect of colored plastic mulch and row cover on air and soil temperatures for okra production in 2003 and 2004 at Shorter, AL. ${ }^{\mathrm{z}}$

\begin{tabular}{|c|c|c|c|c|}
\hline \multirow[b]{3}{*}{ Mulch color } & \multicolumn{2}{|c|}{ With row cover } & \multicolumn{2}{|c|}{ Without row cover } \\
\hline & Air & Soil & Air & Soil \\
\hline & \multicolumn{4}{|c|}{2003 temp $\left({ }^{\circ} C\right)^{y}$} \\
\hline Blue & $38.9 \mathrm{ab}^{\mathrm{x}}$ & $30.3 \mathrm{a}$ & $34.2 \mathrm{ab}$ & $31.0 \mathrm{a}$ \\
\hline Black & $38.4 \mathrm{ab}$ & $30.1 \mathrm{a}$ & $33.7 \mathrm{ab}$ & $30.1 \mathrm{~b}$ \\
\hline Bare soil & $36.5 \mathrm{c}$ & $27.9 \mathrm{c}$ & $33.0 \mathrm{c}$ & $28.8 \mathrm{c}$ \\
\hline Red & $38.0 \mathrm{~b}$ & $30.2 \mathrm{a}$ & $33.5 \mathrm{bc}$ & $30.5 \mathrm{~b}$ \\
\hline Silver & 39.7 a & $27.5 \mathrm{c}$ & $33.5 \mathrm{bc}$ & $27.5 \mathrm{~d}$ \\
\hline \multirow[t]{2}{*}{ White } & $38.4 \mathrm{ab}$ & $28.9 \mathrm{~b}$ & $34.3 \mathrm{a}$ & $28.5 \mathrm{c}$ \\
\hline & \multicolumn{4}{|c|}{2004 temp $\left({ }^{\circ} \mathrm{C}\right)$} \\
\hline Blue & $34.1 \mathrm{bc}$ & $31.6 \mathrm{a}$ & 31.7 & $32.9 \mathrm{a}$ \\
\hline Black & $37.5 \mathrm{a}$ & $31.2 \mathrm{a}$ & 32.2 & $32.2 \mathrm{ab}$ \\
\hline Bare soil & $31.1 \mathrm{c}$ & $27.1 \mathrm{c}$ & 33.2 & $28.9 \mathrm{c}$ \\
\hline Red & $34.6 \mathrm{ab}$ & $30.8 \mathrm{a}$ & 32.3 & $31.7 \mathrm{~b}$ \\
\hline Silver & $36.8 \mathrm{ab}$ & $28.6 \mathrm{~b}$ & 33.0 & $28.2 \mathrm{c}$ \\
\hline White & $36.1 \mathrm{ab}$ & $29.2 \mathrm{~b}$ & 32.1 & $28.3 \mathrm{c}$ \\
\hline
\end{tabular}

${ }^{\mathrm{z}}$ Soil temperature to a depth of 4 inches $(10.2 \mathrm{~cm})$ and air temperature 5 inches $(12.7 \mathrm{~cm})$ above ground level were recorded daily over the time during which the row cover was present.

y $\left(1.8 \times{ }^{\circ} \mathrm{C}\right)+32={ }^{\circ} \mathrm{F}$

${ }^{x}$ Mean separation within columns was determined by Fisher's least significant difference test. Means with different lower case letters are significantly different at $P<0.05$. Means followed by no letter were not significantly different at $P<0.05$. 
treatments producing a slightly higher percentage of marketable fruit than those without covers.

Okra marketable and cull yields for 2004 are shown in Table 4. Yield trends in 2004 were roughly similar to those in 2003. Early yields were greater without a row cover than with one. There was no significant difference between row cover treatments for combined total yield. This was the result of red and blue plastic mulch treatments producing greater yields without a row cover. Despite these two exceptions, by the end of harvest, plots with a row cover produced significantly more marketable yield than those without a row cover. Early marketable plus cull yields were similar for blue and black mulches and lowest with bare soil. This trend continued through to harvest. Plastic mulch has been identified for its ability to produce earlier okra yields than bare soil (Incalcaterra and Vetrano, 2000; Simone et al., 2002). In our study the results were inconsistent on this point. Bare soil always produced the lowest early yield; however, the difference was only significant in 2004.

At harvest, marketable yield was higher with row cover than without; however, the total combined yield with row cover was not significantly higher. Blue and black plastic mulches gave the highest early marketable plus
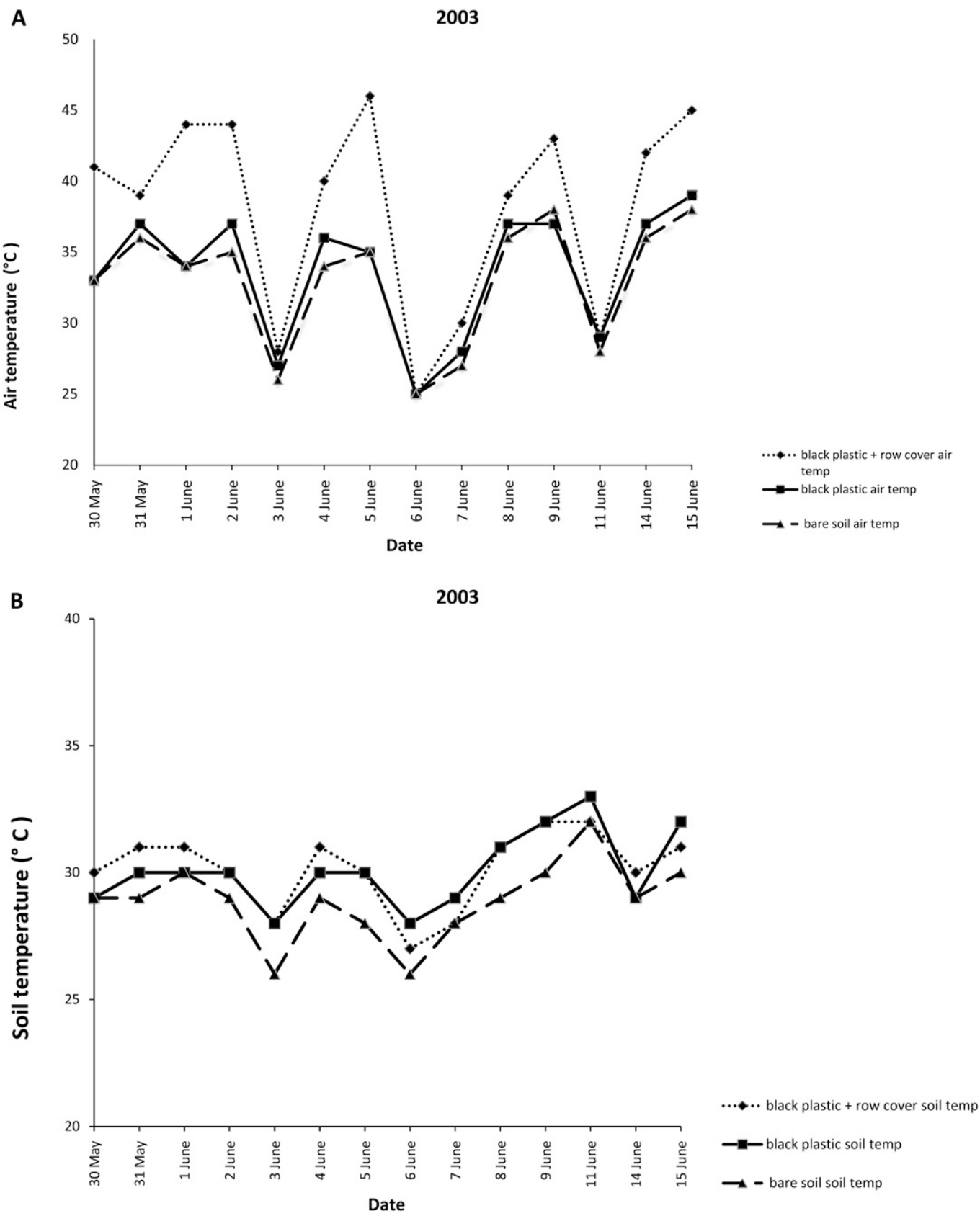

Fig. 1. Temperature reading for 30 May through 15 June 2003, the time period when row covers were present, for okra grown under black plastic mulch with and without row covers and bare soil. (A) Air temperature recorded 5 inches (12.7 $\mathrm{cm})$ above each plot. (B) Soil temperature recorded 4 inches $(10.2 \mathrm{~cm})$ below soil surface in each plot; $\left(1.8 \times{ }^{\circ} \mathrm{C}\right)+32={ }^{\circ} \mathrm{F}$. 
cull yield and gave the two highest total combined yields, significantly higher than all but white plastic mulch. Bare soil had the lowest total marketable yield of all treatments; this was true for BS and BS + RC. Cull yields were $26 \%$ and $28 \%$ of the combined total for treatments with and without a row cover, respectively. Combined total yield for mulch treatments for each row cover followed the order: $\mathrm{BPM}+\mathrm{RC} \geq \mathrm{WPM}+\mathrm{RC} \geq$
$\mathrm{BLUPM}+\mathrm{RC} \geq \mathrm{SPM}+\mathrm{RC} \geq \mathrm{RPM}+$ $\mathrm{RC}>\mathrm{BS}+\mathrm{RC}$ and $\mathrm{BLUPM} \geq \mathrm{BPM} \geq$ $\mathrm{RPM}=\mathrm{WPM}=\mathrm{SPM}>\mathrm{BS}$ for treatments with and without row covers, respectively (data not shown). Brown and Lewis (1986) and Khan et al.

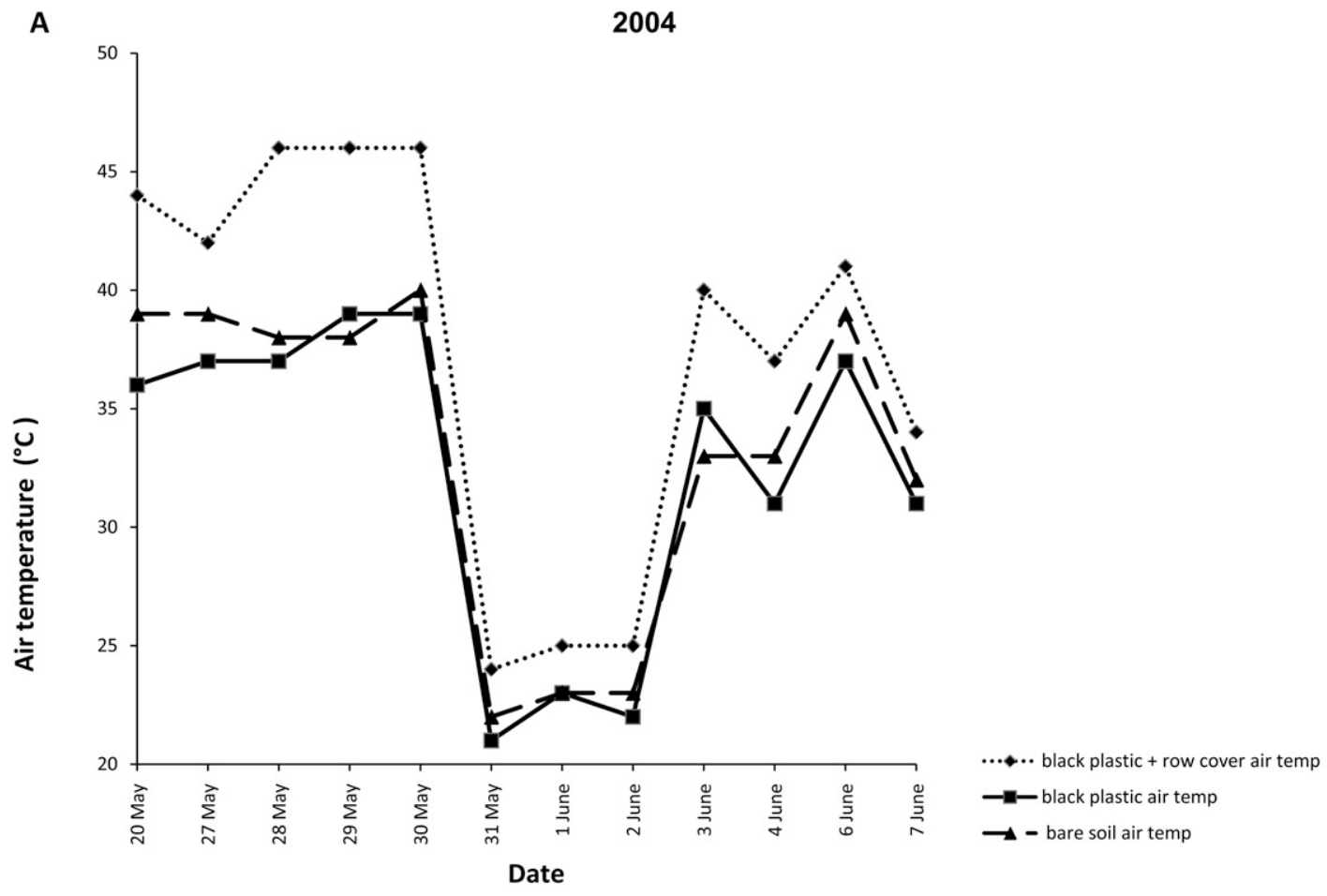

B

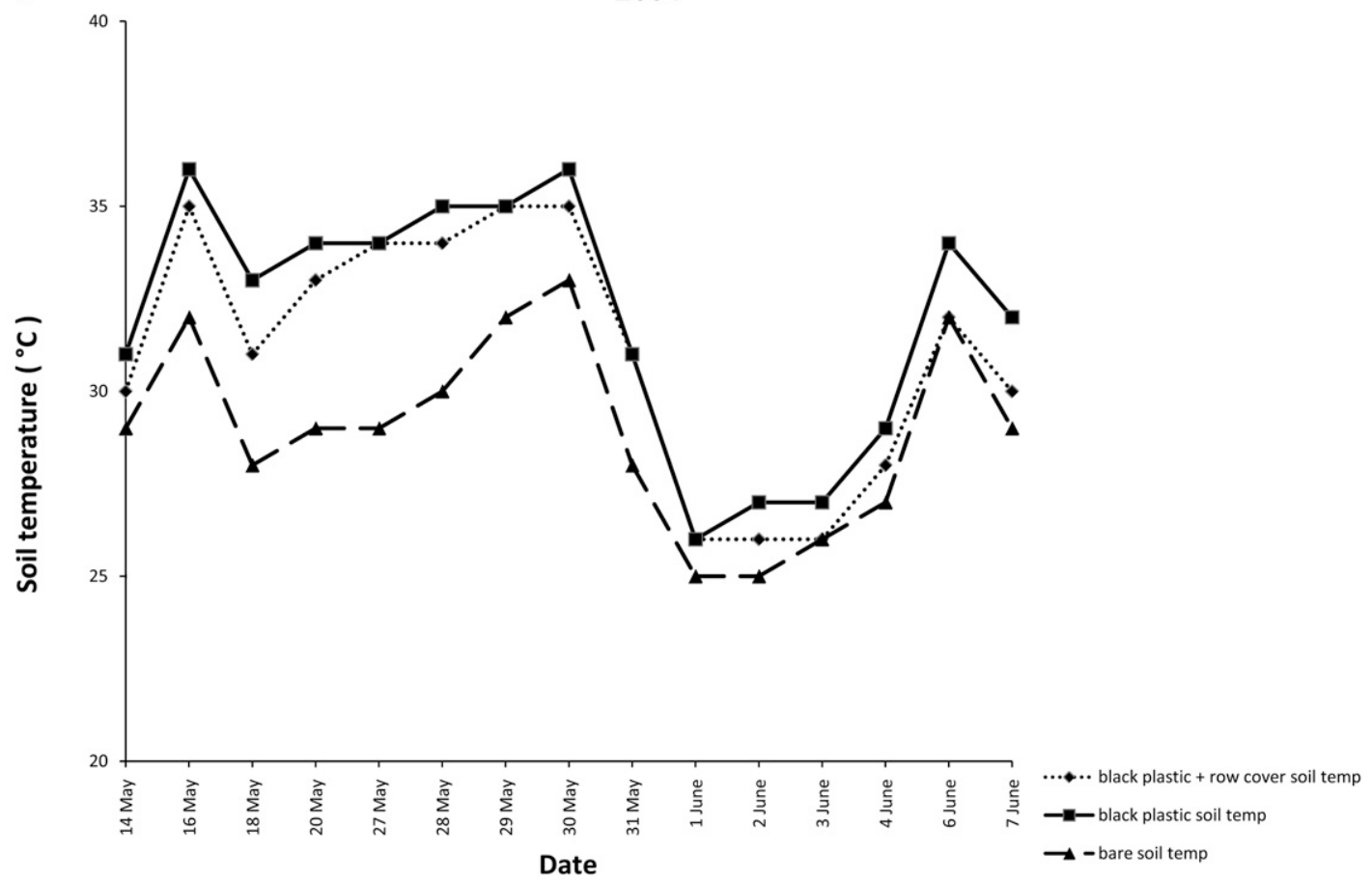

Fig. 2. Temperature reading for 20 May through 7 June 2004, the time period when row covers were present, for okra grown under black plastic mulch with and without row cover and bare soil. (A) Air temperature recorded 5 inches (12.7 $\mathrm{cm}$ ) above each plot. (B) Soil temperature recorded 4 inches $(10.2 \mathrm{~cm})$ below the soil surface in each plot; $\left(1.8 \times{ }^{\circ} \mathrm{C}\right)+32={ }^{\circ} \mathrm{F}$. 
(1990) also found black plastic mulch with a row cover produced higher okra yield than bare soil.

The data for mulch color, row cover, year, and mulch row cover interaction show significant effects on both air and soil temperature at $P<0.01$ (Table 2). In general, plots with row cover had higher air temperatures than plots without row cover (Table 5). In 2003, row cover had no effect on soil temperature. In $2004,1{ }^{\circ} \mathrm{C}$ higher temperatures were recorded in most plots without than with a row cover. The differences in soil temperature between plots with and without row cover were significant but not likely important. Temperature data for each year were analyzed separately.

Black plastic mulch is the standard color of mulch used in horticulture. Figure 1A shows that in 2003, black plastic mulch with row cover had a higher air temperature than black plastic mulch without row cover or bare soil. The black plastic mulch with row cover averaged $4{ }^{\circ} \mathrm{C}$ higher air temperature compared with black plastic mulch and $5{ }^{\circ} \mathrm{C}$ higher air temperature compared with bare soil. In 2004 (Fig. 2A), air temperatures were an average of $6{ }^{\circ} \mathrm{C}$ higher for black plastic mulch with row cover treatment compared with black plastic mulch and $5{ }^{\circ} \mathrm{C}$ higher compared with bare soil. Okra mean air and soil temperatures are shown in Table 5 for 2003 and 2004. In 2003, most plots with plastic mulch plus row cover had statistically similar air temperatures. However, BS + RC had a lower air temperature than other plots with a row cover. During 2004, in plots with a row cover, only BLUPM + RC failed to generate higher air temperatures than BS + RC. These findings are in agreement with other researchers who found higher air temperatures with the use of plastic mulch (Bonanno and Lamont, 1987; Brown and Channell-Butcher, 1999a; IbarraJiménez et al., 2004; Khan et al., 1990). Without a row cover, WPM, BLUPM, and BPM had higher air temperatures than BS treatments in 2003. In 2004, there were no differences in treatments without row covers.

In 2003, soil temperatures were hotter under black plastic (Fig. IB) than under black plastic with row cover or bare soil. Like 2003, soil temperatures for 2004 (Fig. 2B) were greater under black plastic mulch than black plastic mulch with row cover or bare soil. The okra soil temperatures for 2003 and 2004 were significantly higher in plots with blue, red, and black plastic mulches both with and without row covers. All of these treatments were darker colored plastic mulches. Díaz-Pérez and Batal (2002) and Rangarajan and Ingall (2001) found cooler temperatures with bare soil than under darkcolored plastic mulch. These findings also agree with Csizinszky et al. (1995) who found blue led to a higher soil temperature than orange, red, aluminum, white, or yellow-colored mulches. Gough (2001) found the warmest soil temperatures under red mulch. Soil temperature, in 2003 , for plots with row cover, followed the order of BLUPM $+\mathrm{RC}=$ $\mathrm{RPM}+\mathrm{RC}=\mathrm{BPM}+\mathrm{RC}>\mathrm{WPM}+$ $\mathrm{RC}>\mathrm{BS}+\mathrm{RC}=\mathrm{SPM}+\mathrm{RC}$. A similar trend was followed in 2004. Soil temperature in plots without a row cover followed the order BLUPM > $\mathrm{RPM}=\mathrm{BPM}>\mathrm{BS}=\mathrm{WPM}>\mathrm{SPM}$ in 2003 with a similar trend in 2004.

Air temperature was negatively correlated with early yield (Table 6). This is likely the result of above normal temperatures early in the season delaying flowering. This would lead to low early yields and the negative correlation with air temperature. Total yield and the number of branches produced by okra plants were positively correlated to air temperature. Soil temperature was positively correlated with early yield, but this relationship diminished by the end of harvest.

Mulch color, row cover, and year had significant effects on plant height, stem diameter, and the number of branches produced by okra plants; mulch color and year had significant effects on okra fresh weight (Table 7).

Table 6. Pearson correlation coefficient for air and soil temperatures versus okra yield components analyzed across mulch, row cover, and year combinations for experiments conducted at Shorter, AL.

\begin{tabular}{lcc}
\hline Pearson correlation coefficient & Air temp $\left({ }^{\circ} \mathbf{C}\right)$ & Soil temp $\left({ }^{\circ} \mathbf{C}\right)$ \\
\hline Early marketable yield & -0.43280 & 0.51026 \\
Early unmarketable yield & -0.28249 & 0.58798 \\
Total marketable yield & 0.52478 & 0.22170 \\
Total unmarketable yield & 0.45840 & 0.18069 \\
Total yield & 0.51701 & 0.21218 \\
No. branches & 0.58546 & 0.20551 \\
\hline
\end{tabular}

Okra plants were taller, had greater fresh weight, and produced more branches with a row cover than without one. However, among the plastic mulch plus row cover treatments, BLUPM + RC produced significantly taller plants than WPM $+\mathrm{RC}$ and SPM + RC in 2003 and 2004; SPM + $\mathrm{RC}$ resulted in the shortest okra plants. Without a row cover, BLUPM and BPM produced taller plants than BS and WPM. Brown and ChannellButcher (1999b) and Saikia et al. (1997) found that the use of plastic mulch with row cover generated taller okra plants than the use of just plastic mulch or bare soil. The stem diameters produced under BPM was either the largest or second largest (2004 with row cover) of any treatment.

There were no differences in okra fresh weight between treatments in 2003. In 2004, the fresh weights with blue, black, and red mulch colors with bare soil regardless of the presence of row cover.

The branch count produced by okra plants grown with a row cover followed the order $\mathrm{BPM}+\mathrm{RC}=$ $\mathrm{WPM}+\mathrm{RC}=\mathrm{BLUPM}+\mathrm{RC} \geq$ $\mathrm{RPM}+\mathrm{RC} \geq \mathrm{SPM}+\mathrm{RC} \geq \mathrm{BS}+\mathrm{RC}$ and $\mathrm{BPM}+\mathrm{RC} \geq \mathrm{BLUPM}+\mathrm{RC}=$ $\mathrm{RPM}+\mathrm{RC} \geq \mathrm{WPM}+\mathrm{RC} \geq \mathrm{SPM}+$ $\mathrm{RC}>\mathrm{BS}+\mathrm{RC}$ in 2003 and 2004, respectively. Without a row cover, the branch count was only significant in 2004 and followed the order WPM $\geq$ $\mathrm{BPM}=\mathrm{BLUPM} \geq \mathrm{RPM}=\mathrm{SPM}>\mathrm{BS}$. Khan et al. $(1990,1998)$ and Rahman and Shadeque (1999) noted that more okra branches developed with plastic mulch with or without row covers than bare soil.

Results from our study show that a row cover can increase yield; however, the presence of a row cover did not reduce the percentage of cull fruit. Black and blue mulch consistently produced plants among the were always significantly greater than 
Table 7. Effects of colored plastic mulch and row cover on okra plant height, stem diameter, fresh weight, and branch count for each mulch by row cover combination in 2003 and 2004 at Shorter, AL.

\begin{tabular}{|c|c|c|c|c|c|c|c|c|}
\hline \multirow[b]{3}{*}{ Mulch color } & $\begin{array}{l}\text { Plant ht } \\
\text { (inches) }^{\mathrm{z}}\end{array}$ & $\begin{array}{l}\text { Stem diam } \\
\text { (inches) }\end{array}$ & $\begin{array}{c}\text { Fresh wt } \\
(\mathrm{lb} / \text { plant })^{\mathrm{z}}\end{array}$ & $\begin{array}{l}\text { Branches } \\
\text { (no.) }\end{array}$ & $\begin{array}{l}\text { Plant ht } \\
\text { (inches) }\end{array}$ & $\begin{array}{l}\text { Stem diam } \\
\text { (inches) }\end{array}$ & $\begin{array}{c}\text { Fresh wt } \\
\text { (lb/plant) }\end{array}$ & $\begin{array}{l}\text { Branches } \\
\text { (no.) }\end{array}$ \\
\hline & \multicolumn{4}{|c|}{ With row over } & \multicolumn{4}{|c|}{ Without row cover } \\
\hline & \multicolumn{8}{|c|}{2003} \\
\hline Blue & $14.8 \mathrm{a}^{\mathrm{y}}$ & $0.51 \mathrm{a}$ & 0.62 & $7.1 \mathrm{a}$ & $11.4 \mathrm{ab}$ & $0.40 \mathrm{a}$ & 0.33 & 4.2 \\
\hline Black & $14.8 \mathrm{a}$ & $0.50 \mathrm{a}$ & 0.42 & $7.9 \mathrm{a}$ & $11.9 \mathrm{a}$ & $0.42 \mathrm{a}$ & 0.35 & 3.7 \\
\hline Bare soil & $11.7 \mathrm{c}$ & $0.40 \mathrm{~b}$ & 0.20 & $4.3 \mathrm{c}$ & $10.1 \mathrm{c}$ & $0.39 \mathrm{ab}$ & 0.24 & 2.3 \\
\hline Red & $13.4 \mathrm{~b}$ & $0.44 \mathrm{~b}$ & 0.35 & $6.8 \mathrm{ab}$ & $10.6 \mathrm{bc}$ & $0.38 \mathrm{ab}$ & 0.22 & 3.4 \\
\hline Silver & $9.0 \mathrm{~d}$ & $0.33 \mathrm{c}$ & 0.37 & $5.3 \mathrm{bc}$ & $10.5 \mathrm{bc}$ & $0.41 \mathrm{a}$ & 0.42 & 3.1 \\
\hline \multirow[t]{2}{*}{ White } & $13.2 \mathrm{~b}$ & $0.48 \mathrm{a}$ & 0.49 & $7.3 \mathrm{a}$ & $8.8 \mathrm{~d}$ & $0.34 \mathrm{~b}$ & 0.22 & 3.8 \\
\hline & \multicolumn{8}{|c|}{2004} \\
\hline Blue & $17.9 \mathrm{ab}$ & $0.59 \mathrm{~b}$ & $0.57 \mathrm{ab}$ & $6.0 \mathrm{ab}$ & $11.4 \mathrm{a}$ & $0.42 \mathrm{ab}$ & $0.31 \mathrm{abc}$ & $4.1 \mathrm{ab}$ \\
\hline Black & $15.6 \mathrm{~cd}$ & $0.68 \mathrm{a}$ & $0.73 \mathrm{a}$ & $6.3 \mathrm{a}$ & $12.4 \mathrm{a}$ & $0.44 \mathrm{a}$ & $0.44 \mathrm{a}$ & $4.3 \mathrm{ab}$ \\
\hline Bare soil & $17.2 \mathrm{~b}$ & $0.23 \mathrm{~d}$ & $0.06 \mathrm{c}$ & $2.4 \mathrm{c}$ & $7.6 \mathrm{c}$ & $0.26 \mathrm{~d}$ & $0.06 \mathrm{~d}$ & $2.5 \mathrm{c}$ \\
\hline Red & 18.6 a & $0.67 \mathrm{ab}$ & $0.51 \mathrm{ab}$ & $5.3 \mathrm{ab}$ & $12.3 \mathrm{a}$ & $0.43 \mathrm{ab}$ & $0.35 \mathrm{ab}$ & $3.9 \mathrm{~b}$ \\
\hline Silver & $14.6 \mathrm{~d}$ & $0.46 \mathrm{c}$ & $0.33 \mathrm{bc}$ & $4.8 \mathrm{~b}$ & $9.1 \mathrm{~b}$ & $0.36 \mathrm{bc}$ & $0.15 \mathrm{~cd}$ & $3.6 \mathrm{~b}$ \\
\hline White & $15.9 \mathrm{c}$ & $0.60 \mathrm{~b}$ & $0.71 \mathrm{a}$ & $5.0 \mathrm{ab}$ & $7.8 \mathrm{bc}$ & $0.30 \mathrm{~cd}$ & $0.22 \mathrm{bcd}$ & $5.0 \mathrm{a}$ \\
\hline
\end{tabular}

${ }^{\mathrm{z}} 1$ inch $=2.54 \mathrm{~cm} ; \mathrm{l} \mathrm{lb}=0.4536 \mathrm{~kg}$.

${ }^{y}$ Mean separation within columns was determined by Fisher's least significant difference test. Means with different lower case letters are significantly different at $P<0.05$. Means followed by no letter were not significantly different at $P<0.05$.

tallest, greatest fresh weight and most prolific branching. Early and total yields were also highest under black and blue mulches.

\section{Conclusion}

In this study, plants grown in soil under a row cover were taller and generally more robust than plants grown without row covers. Marketable yield was greater with the use of a row cover. In contrast, early yields were reduced by the presence of row cover. This is attributed to the high air temperature in late May associated with row covers. At times, air temperature surpassed $38{ }^{\circ} \mathrm{F}$ in plots containing a row cover. Soil temperatures were 5 to $7^{\circ} \mathrm{C}$ lower than air temperatures. The dark colors, black, blue, and red, resulted in higher soil temperatures than silver or whitecolored mulches. Warmer air and soil temperatures did not always correlate to greater yield. Early yield was generally greatest with dark mulch colors and the combined total yield greatest with black and blue plastic mulch.

Fields et al. (2004) estimated production cost of okra in Alabama without plastic mulch or row cover to be $\$ 2834.32 /$ acre. The price of black plastic mulch is estimated at $\$ 252.00 /$ acre and a row cover at $\$ 637.00$ /acre. Mossler and Dunn (2005) have given a price as high as $\$ 1.66 / \mathrm{lb}$ for okra. The profit of marketable okra produced using a row cover was $\$ 1.37$ versus $\$ 1.35$ per pound without a cover in 2003 and $\$ 1.28$ versus $\$ 1.29$ per pound in 2004. Combining row covers with plastic mulch did not give an advantage to the grower over plastic mulch alone. At locations where cool earlyseason temperatures do not occur, installing a row cover may increase yield, but the additional yield may not be sufficient to increase the return on investment. Plastic mulch did increase yield over bare soil. Even the least productive plastic mulch color (silver in 2003 and red in 2004) increased profitability over bare soil by $\$ 0.10$ and $\$ 0.55$ per pound in 2003 and 2004, respectively. Neither plastic mulch nor row cover had a great influence on the percentage of fruit lost as cull. There was no analysis of the effects of different colored mulch on insect and disease pressure.

Blue plastic mulch produced plant height, fresh weight, and early and total yield comparable to black plastic. The FR:R and blue light reflectance from the various plastic mulches was not measured during this experiment. It is possible that the FR:R and blue light reflected from the plastic mulches could have improved okra growth and yield. Decoteau et al. (1989) and Hatt et al. (1993) found the FR:R ratio had a positive effect on vegetable crops. Blue plastic mulch is $\approx \$ 0.08$ per foot more expensive than black plastic. Our data do not show an economic advantage for blue over black mulch for okra, but the positive effect cited by other authors may be more pronounced with leafy vegetables. More research needs to be done to know the effect that row covers with various colored plastic mulches have on the earliness and production of vegetable crops.

\section{Literature cited}

Akoyunoglou, G., H. Anni, and K. Kalosaka. 1980. The effect of light quality and the mode of illumination on chloroplast development in etiolated bean leaves, p. 473-484. In: H. Senger (ed.). The blue light syndrome. Springer-Verlag, Berlin, Germany.

Antonious, G.F., M.J. Kasperbauer, and M.E. Byers. 1996. Light reflected from colored mulches to growing turnip leaves affects glucosinolate and sugar contents of edible roots. Photochem. Photobiol. 64: 605-610.

Arancibia, R.A. and C.E. Motsenbocker. 2002. Effect of colored mulch and spunbonded polyester row cover on watermelon production. Proc. Natl. Agr. Plastics Congr. 30:127(Abstr.).

Bonanno, A.R. and W.J. Lamont. 1987. Effect of polyethylene mulches, irrigation method, and row cover on soil and air temperature and yield of muskmelon. J. Amer. Soc. Hort. Sci. 112:735738 . 
Brown, J.E. and C. Channell-Butcher. 1999a. Effects of row cover and black plastic mulch yield of 'AU Producer' watermelon on hilled and flat rows. J. Veg. Crop. Production 5:67-71.

Brown, J.E. and C. Channell-Butcher. 1999b. Effect of three row covers and black plastic mulch on the growth and yield of 'Clemson Spineless' okra. J. Veg. Crop. Production 5:67-71.

Brown, J.E. and C. Channell-Butcher. 2001. Black plastic mulch and drip irrigation affect growth and performance of bell pepper. J. Veg. Crop Production 7:109112.

Brown, J.E., S.P. Kovach, W.D. Goff, D.G. Himelrick, K.M. Tilt, W.S. Gazaway, L.M. Curtis, and T.W. Tyson. 1995. Fumigation and mulch affect yield, weight, and quality of 'Pimiento' pepper, Capsicum annuиm L. J. Veg. Crop Production $1: 71-80$.

Brown, J.E. and G.A. Lewis. 1986. Influence of black plastic mulch and row cover on the growth and performance of okra intercropped with turnip greens. Proc. Natl. Agr. Plastics Congr. 19:148-157.

Brown, J.E., F.W. Woods, and C. ChannellButcher. 1998. Effect of black plastic mulch and row cover on sweet potato production. J. Veg. Crop. Production 4:49-55.

Contreras Magana, E. and F. Sánchez del Castillo. 1990. Preliminary trial of the performance of squashes (Cucurbita pepo L.), snap beans (Phaseolus vulgaris L.) and cucumbers (Cucumis sativus L.) with mulching and row covers. Revista Chapingo 15:34-38.

Csizinszky, A.A., D.J. Schuster, and J.B. King. 1995. Color mulches influence yield and pest populations in tomatoes. J. Amer. Soc. Hort. Sci. 120:778-784.

Decoteau, D.R., M.J. Kasperbauer, D.D. Daniels, and P.G. Hunt. 1988. Plastic mulch color effects on reflected light and tomato plant growth. Scientia Hort. 34:169-175.

Decoteau, D.R., M.J. Kasperbauer, and P.G. Hunt. 1989. Mulch surface color affects yield of fresh-market tomatoes. J. Amer. Soc. Hort. Sci. 114:216-219.

Decoteau, D.R., M.J. Kasperbauer, and P.G. Hunt. 1990. Bell pepper plant development over mulches of diverse colors. HortScience 25:460-462.

Decoteau, D.R., S.B. Wilson, and C.L. Ray. 1993. A plant physiologist view of the perception of light and color by plants. Proc. Natl. Agr. Plastics Congr. 24:158163.

Díaz-Pérez, J.C. and D. Batal. 2002. Colored plastic film mulches affect to- mato growth and yield via changes in root-zone temperature. J. Amer. Soc. Hort. Sci. 127:127-136.

Díaz-Péréz, J.C., D. Batal, D. Bertrand, and D. Giddings. 2000. Colored plastic mulches effect growth and yield of tomato plants via changes in soil temperature. Proc. Natl. Agr. Plastics Congr. 29:547552.

Dodds, G.T., C.A. Madramootoo, D. Janik, E. Fava, and A. Stewart. 2003. Factors affecting soil temperatures under plastic mulches. Trop. Agr. (Trinidad) 80:6-13.

Farías-Larios, J.M.O.-S. and J. Perez. 1998. Effect of plastic mulch, floating row covers and microtunnels on insect population and yield of muskmelon. Proc. Natl. Agr. Plastics Congr. 27:76-83.

Fields, D., R.L. Rainey, R.A. Hinson, J.G. Black, and C.R. Hall. 2004. Vegetable planning budgets Alabama, 2004. Auburn Univ. Dept. Agr. Econ. Rural Sociology, AEC-BUD 1-1.

Gerber, J.M. and J.E. Brown. 1982. Effect of plastic mulch, row covers and hot caps on the yield and earliness of muskmelons. Illinois Veg. Growers Schools, Univ. Illinois, Urbana. Hort. Ser. 31:48-50.

Gough, R.E. 2001. Color of plastic mulch affects lateral root development but not root system architecture in pepper. HortScience 36:66-68.

Ham, J.M., G.J. Kluitenberg, and W.J. Lamont. 1991. Potential impact of plastic mulches on the aboveground plant environment. Proc. Natl. Agr. Plastics Congr. 23:63-69.

Hanna, H.Y., R.L. Parish, and R.P. Bracy. 2003. Reusing black polyethylene mulch saves money in the vegetable business. Louisiana Agr. Winter:21-22.

Hart, J.W. 1988. Light and plant growth. Unwin Hyman, London, UK.

Hatt, H.A., M.J. McMahon, D.E. Linvill, and D.R. Decoteau. 1993. Influence of spectral qualities and resulting soil temperatures of mulch films on bell pepper growth and production. Proc. Natl. Agr. Plastics Congr. 24:233-238.

Ibarra, L., J. Flores, and J.C. Díaz-Pérez. 2001. Grow and yield of muskmelon in response to plastic mulch and row covers. Scientia Hort. 87:139-145.

Ibarra-Jiménez, L., M.R. Quezada-Martin, and M. de la Rosa-Ibarra. 2004. The effects of plastic mulch and row covers on the growth and physiology of cucumber. Aust. J. Exp. Agr. 44:91-94.

Incalcaterra, G. and F. Vetrano. 2000. Effects of two sowing dates and plastic mulch on okra production. Acta Hort. 533:329-336.

Kasperbauer, M.J. 1992. Phytochrome regulation of morphogenesis in green plants: From Beltsville spectrograph to colored mulch in the field. Photochem. Photobiol. 56:823-832.

Kasperbauer, M.J. 1999. Colored mulch for food crops. Chemtech 29:45-50.

Kasperbauer, M.J. and J.H. Loughrin. 2004. Butterbean seed yield, color and protein content are affected by photomorphogenesis. Crop Sci. 44:2123-2126.

Kasperbauer, M.J. and D.P. Thibodeaux. 1997. Light environment of the developing boll affect cotton fiber length. Proc. Beltwide Cotton Conf. 2:1490-1491.

Khan, V.A., C. Stevens, and J.E. Brown. 1990. Early response of transplanted okra grown under Vispore ${ }^{\circledR}$ row cover and two types of polyethylene mulch. Proc. Natl. Agr. Plastics Congr. 22:28-32.

Khan, V.A., C. Stevens, M.A. Wilson, D.J. Collins, J.E. Brown, E.C.K. Igwegbwe, and J.Y. Lu. 1998. The effect of clear and black polyethylene and paper mulches with Reemay® row cover and three row planting patterns on okra production. Proc. Amer. Soc. Plastics Congr. 27:84-92.

Lamont, W.J. 1993. Plastic mulch for the production of vegetable crops. HortTechnology 3:35-39.

Lamont, W.J., M.D. Orzolek, L. Otjen, and T. Simpson. 2000. Production of potatoes using plasticulture. Proc. Natl. Agr. Plastics Congr. 29:599-601.

Lamont, W.J., K.A. Sorensen, and C.W. Averre. 1990. Painting aluminum strips on black plastic mulch reduces mosaic symptoms on summer squash. HortScience 25:1305.

Leib, B.G., A.R. Jarrett, M.D. Orzolek, and R.O. Mumma. 2002. Drip chemigation of imidacloprid under plastic mulch increased yield and decreased leaching caused by rainfall. Trans. Amer. Soc. Agr. Eng. 43:615-622.

Lipson, E.D. 1980. Sensory transduction in Phycomyces photoresponses, $\mathrm{p}$. 110-118. In: H. Senger (ed.). The blue light syndrome. Springer-Verlag, Berlin, Germany.

Loughrin, J.H. and M.J. Kasperbauer. 2002. Aroma of fresh strawberries is enhanced by ripening over red versus black mulch. J. Agr. Food Chem. 50:161-165.

Mossler, M.A. and E. Dunn. 2005. Florida crop pest management profile: Okra. 1 Mar. 2008. <http://edis.ifas.ufl.edu/ PI097>. 
Orzolek, M.D. and J.H. Murphy. 1993. The effect of colored polyethylene mulch on yield of squash and pepper. Proc. Natl. Agr. Plastics Congr. 24:157-161.

Orzolek, M.D., L. Otjen, and J.E. Fleck. 2000. Uptake effect of colored mulch on tomato production. Proc. Natl. Plastics. Congr. 29:324-329.

Powell, N.L. 2000. Watermelon production with red and black plastic mulch in southeast Virginia. Proc. Natl. Agr. Plastics Congr. 29:622-627.

Pratt, L.H. 1982. Phytochrome: The protein moiety. Annu. Rev. Plant Physiol. 33: 557-582.

Purser, J. 1993. Plastic mulch and row covers to produce warm season crops in Alaska. Proc. Natl. Agr. Plastics Cong. 24:49-53.

Rahman, N. and A. Shadeque. 1999. Comparative efficacy of mulches with or without an herbicide on growth and yield of lady's finger [Abelmoschus esculentus (L.) Moench (Var. Vijaya)]. J. Agr. Sci. Soc. North East India 12:123-127.

Rajapakse, N.C. and J.W. Kelly. 1994. Problems of reporting spectral quality and interpreting phytochrome-mediated responses. HortScience 29:1404-1407.
Rangarajan, A. and B. Ingall. 2001. Mulch color effects radicchio quality and yield. HortScience 36:1240-1243.

Ruyters, G. 1982. Effects of blue light on pyruvate kinase activity during chloroplasts development of unicellular green algae [Chlorella vulgaris]. Photochem. Photobiol. 35:229-231.

Saikia, S., A. Saikia, A. Shadeque, and S. Gogoi. 1997. Field performance of okra as influenced by low density plastic mulches. Ann. Biol. 13:253-257.

Senger, H. and W. Schmidt. 1994. Diversity in photoreceptors, p. 301-324. In: R.E. Kendrick and G.H.M. Kronenberg (eds.). Photomorphogenesis in plants. 2nd Ed. Kluwer Academic, Dordrecht, The Netherlands.

Shadbolt, C.A., O.D. McCoy, and F.L. Whiting. 1962. The microclimate of plastic shelters used for vegetable production. Hilgardia 32:251-266.

Shropshire, W., Jr. 1980. Carotenoids as primary photoreceptors in blue-light responses, p. 172-186. In: H. Senger (ed.). The blue light syndrome. Springer-Verlag, Berlin, Germany.
Simone, E., B. Hochmuth, J. Simmons, E. Vinson, and A. Caytor. 2002. Evaluation of new okra cultivars for bare ground and plasticulture production. Hort Technology 12:470-476.

Summers, C.G. and J.J. Stapleton. 2002. Use of UV reflective mulch to delay the colonization and reduce severity of Bemesia argentifolii (Homoptera: Aleyrodidae) infestations in cucurbits. Crop Prot. 21: 921-928.

Vierstra, R.D., M.M. Cordonnier, L.H. Pratt, and P.H. Quail. 1984. Native phytochrome: Immunoblot analysis of relative molecular mass and in vitro proteolytic degradation for several plant species. Planta 160:521-528.

Wells, O.S. and J.B. Loy. 1985. Intensive vegetable production with row covers. HortScience 20:822-825.

Wolfe, D.W., L.D. Albright, and J. Wyland. 1989. Modeling row cover effects on microclimate and yield: I. Growth response of tomato and cucumber. J. Amer. Soc. Hort. Sci. 14:562568 . 